\title{
Winnie's Diasporic Experiences: A Journey for Searching a Better Life
}

\author{
${ }^{1}$ Riana Permatasari, Dini Nur Islamiyati ${ }^{2}$ \\ Universitas Islam Sultan Agung, Jl. Raya Kaligawe Km.4 Semarang, Indonesia \\ \{1ermatasari@unissula.ac.id, ${ }^{2}$ handiny6@gmail.com $\}$
}

\begin{abstract}
Diaspora has been a cultural issue for decades discussed in literary works. It is caused by many reasons including political, economic, and cultural factors. This study aims at analyzing the diaspora experienced by Winnie, the main character in The Kitchen's God Wife Novel. This study belongs to a qualitative study involving four steps: (a) reading the novel, (b) identifying the data in the form of dialogues and monologues, (c) classifying the data, and (d) analyzing the data. Based on the findings, Winnie's diaspora is caused by various conflicts in the homeland in which the war happened in China due to the Japan's invasion to China. She and other Chinese people have to move from one city to another city because the war has affected many areas in China. Their lives are obstructed because there are many chaotic situations in many fields including economic, transportation, and social welfare. She is lucky as she leaves China right before the borders are sealed from other countries. Moreover, another issue is also highlighted in the story; her father is accused for being a traitor because he has a business connection with Japan. These facts become the reasons she does diaspora. In conclusion, Winnie's journey in leaving China is not easy but she believes that leaving China and living in the United States of America (USA) will make her life better.
\end{abstract}

Keywords: diaspora, reasons for doing diaspora, Kitchen's God Wife

\section{INTRODUCTION}

Diaspora has been a cultural issue starting by the migration of Jewish in the past when Jewish people moved from their homeland to Babylon. Diaspora itself is defined as "a metaphor designation to describe different categories of people expatriates, expellees, political refugees, alien residents, immigrants and ethnic, and racial minorities tout court [5]." Thus, based on the assertion of Loktongbam [5]) diaspora is not simply done by an individual with personal reasons, but it is done by many people correlating with public reasons in economics, political, or socio-cultural aspects. In other words, it can be stated that they move because of an urgent or emergency issue in their country.

Furthermore, Simona [7] also asserts that there are many reasons people do diaspora including economic, political, and cultural factors. This notion highligts that security and prosperity become an important goal to achieve when people do diaspora. They think they can escape from the confilict they face in their homeland by moving to other country or called diaspora. 
This is also alligned with what Brah [1] conveys that "The journey of people as a result of expulsion, persecution, forced to flee in the wake of political strife, conflict, and war, or a population movement." Brah also gives more attentation to diaspora happens not as comfortable journey, but as a journey due to external factors such as politics, war, and other conflicts. People doing diaspora choose to move from their homeland to the hostland than living with anxiety in their homeland because there are a lot of conflicts they have to face. Thus, the movement of migration is needed by the people in facing the conflicts in their homeland.

The issue of diaspora has been illustrated in literary works; one of them is The Kitchen God's Wife by Amy Tan. In the novel, it is narrated the struggles of the main character, Winnie, who moved from her homeland to the host land with other Chinese people. She and other Chinese people moved to the United States of America after the communist came to their homeland and post war happened in China. The situation was very chaotic at that time that made the people felt insecure in the homeland. Before all the transportations were banned by the communists, she and other Chinese people left China and moved to the host land which is the United States of America (USA). They together did diaspora with hoping for more comfortable life in the hostland.

The issue of diaspora as done by Winnie and other Chinese immigrants still exists untill nowadays because war still happens in some areas in this world that forces them being refugees in other countries so that discussing diaspora is still relevant nowadays. In brief, this study aimed at analyzing the reasons for doing diaspora of Winnie as depicted in The Kitchen God's Wife.

\subsection{THEORETICAL REVIEW}

\section{a. Diaspora}

Diaspora is sometimes understood as migration in the a broad sense as these two words is explained as a movement from the homeland to the host land. However, there is a specific different between diaspora and migration. Migration is "the crossing of a spatial boundary by one or more persons involved in a change of residence [4]", whereas diaspora is used to illustrate "types of people expatriate, expel-lees, political refugees, alien residents, immigrant and ethnic, and racial minorities tout court [5]." From these two definitions, it is clear that diaspora is not as simple as migration in which someone moves from one place to another place. However, diaspora is correlated with more complicated situations involving many issues including political, economic, and socio-cultural conflicts that make people who do diaspora is regarded as refugees or other terms used by Loktongbam [5]. By understanding the distinction between the word migration and diaspora, it will be clearer in discussing further about diaspora.

In addition, diaspora is also explained as "a movement, a journey, or travel from a homeland to the host land to live and re-live, to produce and re-produce, and to transform and re-transform [1]." This definition uses the word to live and re-live meaning that they move to another place for having a new life and new hopes. Immigrants may have different ways of live as well as ways of thinking in the host land and in the homeland. Living in the host land brings immigrants a new experience in their life. The words produce and re-produce as well as transform and re-transform also indicate they deal with new environment so they will contact with new cultures so that they will re-produce and re-transform based on their contacts with the new cultures further related to acculturation process. It makes diaspora cannot be separated from cultural issues but it directly belongs to cultural issue itself. . 
Moreover, Simona [7] explains there are several reasons causing people do diaspora such as "a desire of prosperity, political issues, family re-unification, escaping conflict or natural disaster, or simply the wish to change one's surrounding." First reason conveyed by Simona is a desire of prosperity that is closely related to economic factors. In the homeland, they face difficulties in economics that makes them live in poverty. Second factor is political issues such as war, etc.

The assertion of Simona [7] is supported by Brah [1] in which he states that people do diaspora "as a result of expulsion, persecution, forced to flee in the wake of political strife, conflict and war, or a population movement." Brah in his statement highlight the political situations become the reasons of people doing diaspora. The wake of political strife in the country can rise problematic and chaotic situation within the country. This makes people living in the country do not find comfortable life and are forced to leave their homeland. In addition, Brubaker [2] also explains that people who have been construed diaspora also sometimes involve in the support of terrorist or ultra-nationalist movements. Their involvements in homeland politics becomes also a major reason for leaving the country.

As we know, one of the ethnics doing diaspora is Chinese. Chinese diaspora is begun with the conflict between Republican and Communist Party in China. Wong [9] assert that, in 1972 to 1949, China faced civil war between Republican and Communist; Communist won and China was under controlled the Communist Party and isolated from other countries for about twenty years as the borders are sealed. During this condition, the socio-economic condition is far from being called as good for the people. They live in a struggling life so that many of them move to another country. This war also led to unstable economic conditions and many social conflicts inside the country. For example, transportation system was banned from in and out the country. This conditions further motivate them for escaping from the conflicts happened in their country and change their surroundings. That is why Chinese people at that time did diaspora together to other countries such as the United States of America (USA) as stated by Schwartz et.al. [6] that USA experienced a huge number of immigrants in $19^{\text {th }}$ and early $20^{\text {th }}$ century.

\section{METHODOLOGY}

This study belongs to a qualitative study as stated by Crescentini and Mainardi [3] that a study can be defined as a qualatitative study based on the epistemological and ontological assumptions meaning that the research is based on the work itself through the text in finding the deep meaning of the text. The qualitative study is appropriate in answering the problem formulation that is Winnie's reasons in doing diaspora in The Kitchen God's Wife Novel. There are three steps in gathering the data from the novel including reading the novel repeatedly, identifying the data in the form of dialogues and monologues, and classifying the data in the table consisting of page where the data found, and the references supporting the data. After the data gathered, the data were analyzed using the theory of diaspora to answer the problem formulation.

\section{FINDINGS AND DISCUSSIONS}

In the novel, it is narrated that Winnie lived in a war era in China, she even did not know when the war began; she just knew that everything was unstable and chaotic as quoted "And then the war began, and I did not know this either, [8]." Winnie and other Chinese people face 
a civil war between China and Japan. There was a chaotic condition when communist party tried to take over China. She even does not know how the war begins but she knows that chaos has started in her country. As stated by Wong [9] that at that time, China suffers from civil war between Republican and Communist Party that make its people should face problems in their daily live. It is aligned with what stated by Brah [1] that the diaspora happens because of the war.

The war created various conflicts in the homeland. The war was spread around China made Chinese people started to move to look for a safe place as what conveyed by Brah [1] that people doing diaspora need to re-live, re-transform, and re produce to be better. The journey in moving from one area to another area is indicated by the following quotations. Winnie says, "So we left for Yangchow at the end of Summer, only a few weeks after the war began. And we went by boat, because by then many roads and railways were already blocked [8]." This quotation indicates that how massive the effects of the war were in the country. Even though it was only few weeks after the war began, the social life of Chinese people was affected in which the land transportation systems were blocked so they went to Yangchow by boat. This situation is also aligned with the situation narrated by Wong [9] explaining that China is sealed from other countries during the war era.

Further, the journey for searching better place to live is not easy for Winnie and other Chinese people. It is because war have affected many areas in China. "We would leave Nanking soon, maybe in two weeks, maybe less. 'We have not been here even one week,' I started to say. Wen Fu was not smiling, and I knew his meaning: The Japanese were coming [8]." Winnie's husband is a soldier so he knows when Japan comes to an area in China. The words "The Japanese were coming" sounds like a bell ringing as a sign that war is about to begin in that area. They have to move from one city to another city for seeking a safe place. This quotation show that they even rarely stayed more than a week in a city.

In addition, Winnie says,

I remember when we finally arrived in a bigger city, Kweiyang. Wen Fu knew a saying about Kweiyang, something like this: 'The sky doesn't last three good days, the land isn't level for even three inches.' That was because it rained all the time. And the city was very bumpy. The buildings and streets went up and down like the back of a dragon. And behind the city stood sharp rocky hills, looking like ancient men, too stiff to move, [8]

In Kweiyang, Winnie and other Chinese see how chaotic the situation is in the city. The tragic look of the city indicates that there is no place in the country that have not been affected by the war. Winnie and other Chinese have to leave the country as refugees of the war as stated by Brah [1].

Another issue in the novel is, Winnie's father is accused for being a traitor because he has a business connection with Japanese. In the following quotation,

Kuomintang soldiers marched to the houses and business of those who had collaborated with the Japanese. Our factories were immediately shut down, until it could be determined what should be done with this traitor to China. Soon after that the Kuomintang came to our house. Your father could say nothing, of course. So I explained what had happened. I told that your father hated the Japanese with all his heart.., 'The Kuomintang said it was still not good excuse, because the public would always believe he had been a traitor' [8]

In the story, it is narrated that Winnie's father has a factory and cooperation with Japanese before the war begins. Those who have collaborations with Japanese are attacked by the nationalist as they are regarded as a traitor. This case does not only happen to Winnie's 
father, but also happens to other Chinese people who have collaborations with Japanese. The involvement of her father in political issue influence her decision for doing diaspora. This situation supports what Brubaker [2] says that some people do diaspora because of their political involvement, terrorist, or ultra-nationalist movement.

After dealing with many complicated and chaotic situation in her homeland, Winnie decides to move to America with other Chinese people. "Lucky for me, six days later I was in America with your father. 5 days after that, the Communist flags went up in Shanghai, no more planes or boats could leave [8]." Winnie is finally in America when the communist takes over China. She builds a new hope in the host land and rearrange her life. She retransforms her dreams and hopes in the host land.

\section{CONCLUSION}

In conclusion, Winnie's journey in doing diaspora is influenced by the chaotic situations because of the war and her father political involvement. Her journey for searching safe place to live is not easy as she has to move from one city to another city and finally arrives in USA with a new hope that her life will be better by living in USA instead of in China.

\section{Reference List}

[1] A. Brah, Thinking through the concept of diaspora. Post-Colonial Studies Reader. $2^{\text {nd }}$ Ed. 443-446, 1996.

[2] R. Brubaker, Ethnics and racial studies. "The Diaspora Diaspora” 28. 1, 1-19, 2005.

[3] A. Crescentini \& G. Mainardi, Qualitative research articles: Guidelines, suggestions, and needs. Qualitative Research Articles 21.5, 431-439, 2009.

[4] P. Kok, The definition of migration and its application: Making sense of South African census and survey data. SA Journal of Demography 7,1, 19-30, 1999.

[5] N. Loktongbam, Chinese diaspora: A study of Amy Tan's The Joy Luck Club. IOSR Journal of Humanities and Social Science (IOSR-JHSS). N.d. 56-59 (Retrieved on March 9, 2017).

[6] S. Schwartz, S. et.al. (2010). Rethinking the concept of acculturation. Implications for Theory and Research, 65,4, 237-251.

[7] Simona, Perspective on identity and acculturation of immigrants in Europe. Journal of Identity and Migration Studies, 8,2, 67-77, 2014.

[8] A. Tan, The Kitchen God's Wife. London: Flamingo, 1991.

[9] M.S.M. Wong, M.S.M. Chinese-American Mothers and Daughters: The Novels of Amy Tan. 1-45, 2007. 